\title{
Analysis of the Influence of the Amount of Labor, Level of Education and Government Spending on Economic Growth in North Sumatera
}

\author{
Janita Sari ${ }^{1}$ Irsad $^{2}$, Rahmanta $^{3}$ \\ ${ }^{1}$ Postgraduate, Students Faculty of Economics and Business, Department of Economics, Universitas North \\ Sumatra, Indonesia \\ ${ }^{2,3}$ Postgraduate, Lecturer Faculty of Economics and Business, Department of Economics, Universitas North \\ Sumatra, Indonesia
}

Corresponding Author: Janita Sari

\begin{abstract}
This study was to analyze the effect of labor, levels of education and government spending on the education sector on economic growth in North Sumatra. The data used is secondary data obtained from the Regional Financial and Asset Management Agency of North Sumatra and the Central Statistics Agency of North Sumatra Province, which consists of 33 districts / cities in several publications from 2015-2019. The research method used is panel data with a Fixed Effect Model approach. The results of this study indicate that labor has a negative and insignificant effect on economic growth, the level of education has a significant positive effect on economic growth and government spending in the education sector has a significant positive effect on economic growth in North Sumatra in 2015-2019.
\end{abstract}

Keywords: Economic Growth, Labor, Education Level and Government Expenditure.

\section{INTRODUCTION}

Economic development is needed by a country to improve the lives and welfare of the community, by developing all areas of activity in a country. In order to improve the welfare of the community it is necessary increased economic growth and income distribution is uneven. Economic growth can be defined as the process of changes in economic conditions of a country continuously toward a better state for a certain period (Hashim, 2017: 11).

Economic growth is an important factor in development, the successful development of a country or region is measured based on the high and low rates of economic growth achieved. Measurement of economic growth is conventionally usually by calculating the increase in the percentage of Gross Domestic Product to national and Regional Gross Domestic Product for the provincial and district/city. Gross Regional Domestic product is the sum of value added generated by all business units in a particular region or is the amount of the value of final goods and services produced by all economic units during a certain period. Therefore, the economic growth of a region can be obtained through the growth rate of the Gross Regional Domestic Product at constant prices. Economic growth as the development of activities in the economy that cause the goods and services produced in a society grow and the prosperity of society increased. So economic growth to measure the achievements of the development of an economy from one period to the other (Sukirno in Suindyah, 2011: 120).

Advance whether a country can be seen from the growth of its economy. Countries with good growth can indirectly indicate the progress of the country, but 
increase the economic growth of a country is not an easy thing, many of the factors that affect the rate of growth of a country. So an economy is said to experience economic growth if the amount of production of goods and services in a given year is greater than in the previous year (Rusdi and Haerati, $2015: 2$ ).

Economic growth in each country is different, therefore, economic growth is not the only concern and the agenda of the central government but also to the attention of the agenda and each region in a country. This is because the economic growth of a country is also affected by economic growth in each region. Included in the Province of North Sumatra which is composed of 33 Districts/Cities that have a background differences between regions. The difference is in the form of differences in the characteristics of the natural, social, economic, and natural resources that its spread is different.

Table 1.1 Economic Growth On The Basis Of Constant Prices North Sumatra Tahun 2015-2019 (Percent)

\begin{tabular}{|l|l|l|l|l|l|}
\hline District/City & $\mathbf{2 0 1 5}$ & $\mathbf{2 0 1 6}$ & $\mathbf{2 0 1 7}$ & $\mathbf{2 0 1 8}$ & $\mathbf{2 0 1 9}$ \\
\hline Nias & 5.43 & 5.03 & 5.01 & 4.95 & 5.04 \\
\hline Mandailing Natal & 6.22 & 6.18 & 6.09 & 5.79 & 5.30 \\
\hline Tapanuli Selatan & 5.02 & 5.12 & 5.21 & 5.19 & 5.23 \\
\hline Tapanuli Tengah & 5.08 & 5.12 & 5.24 & 5.20 & 5.18 \\
\hline Tapanuli Utara & 4.81 & 4.12 & 4.15 & 4.35 & 4.62 \\
\hline Toba Samosir & 4.55 & 4.76 & 4.90 & 4.96 & 4.88 \\
\hline Labuhan Batu & 5.04 & 5.06 & 5.00 & 5.06 & 5.07 \\
\hline Asahan & 5.57 & 5.62 & 5.48 & 5.61 & 5.64 \\
\hline Simalungun & 5.24 & 5.40 & 5.13 & 5.18 & 5.20 \\
\hline Dairi & 5.04 & 5.07 & 4.93 & 5.01 & 4.82 \\
\hline Karo & 5.01 & 5.17 & 5.21 & 4.55 & 4.60 \\
\hline Deli Serdang & 5.25 & 5.32 & 5.10 & 5.15 & 5.18 \\
\hline Langkat & 5.03 & 4.98 & 5.05 & 5.02 & 5.07 \\
\hline Nias Selatan & 4.46 & 4.41 & 4.56 & 5.02 & 5.03 \\
\hline Humbang Hasundutan & 5.24 & 5.00 & 5.02 & 5.04 & 4.94 \\
\hline Pakpak Bharat & 5.93 & 5.97 & 5.94 & 5.85 & 5.87 \\
\hline Samosir & 5.77 & 5.27 & 5.35 & 5.58 & 5.7 \\
\hline Serdang Bedagai & 5.05 & 5.14 & 5.16 & 5.17 & 5.28 \\
\hline Batu Bara & 4.11 & 4.44 & 4.11 & 4.38 & 4.35 \\
\hline Padang Lawas Utara & 5.94 & 5.96 & 5.54 & 5.58 & 5.61 \\
\hline Padang Lawas & 5.74 & 6.06 & 5.71 & 5.96 & 5.64 \\
\hline Labuhanbatu Selatan & 5.13 & 5.19 & 5.09 & 5.27 & 5.35 \\
\hline Labuanbatu Utara & 5.18 & 5.21 & 5.11 & 5.2 & 5.15 \\
\hline Nias Utara & 5.49 & 4.59 & 4.43 & 4.42 & 4.65 \\
\hline Nias Barat & 4.87 & 4.83 & 4.81 & 4.77 & 4.82 \\
\hline Sibolga & 5.65 & 5.15 & 5.27 & 5.25 & 5.2 \\
\hline Tanjungbalai & 5.58 & 5.76 & 5.51 & 5.77 & 5.79 \\
\hline Pematangsiantar & 5.24 & 4.86 & 4.41 & 4.8 & 4.82 \\
\hline Tebing Tinggi & 4.86 & 5.11 & 5.14 & 5.17 & 5.15 \\
\hline Medan & 5.74 & 6.27 & 5.81 & 5.92 & 5.93 \\
\hline Binjai & 5.4 & 5.54 & 5.39 & 5.46 & 5.51 \\
\hline Padangsidimpuan & 5.04 & 5.29 & 5.32 & 5.45 & 5.51 \\
\hline Gunung Sitoli & 5.39 & 6.03 & 6.01 & 6.03 & 6.05 \\
\hline & $P .90$ & & \\
\hline
\end{tabular}

Source: BPS Province North Sumatra
These differences become an obstacle in the distribution of economic development because economic growth is only concentrated on an economic activity that is increased in some provinces or regions that have abundant natural resources. The natural wealth that should dapatmenjadikan added value in improving economic development in the Province of North Sumatra.

Based on the 33 districts/cities in North Sumatra for 2015 economic growth of the Coal District is located on the lowest level, namely 4,11\%, while the District lines are Mandailing Natal by 6,22\%. 2016 Distric Tapanuli Utara is located on the lowest level, namely were $4.12 \%$ and the Terrain into Districts/city with the highest economic growth of 6,27\%. 2017 economic growth of the Coal back into the District the lowest is $4,11 \%$, and Mandailing Natal Regency becomes the highest 6,09\%. 2018 North Tapanuli Regency is located on the lowest level, namely 4.35 percent, and Gunung Sitoli District the highest 6,03\%. For the year 2019 again the Coal Districts of the low of 4.35 percent, and the Gunungsitoli Sitoli back be the District with the highest economic growth that is equal $6,05 \%$.

In 2015 economic growth of $5.10 \%$ is, the year 2016 is slightly increased from the year previous $5,18 \%$, but the year 2017 economic growth in North Sumatra experienced a slowdown to the $5.12 \%$, and then increased slightly in 2018 by $5.18 \%$ on the value, up to the year 2019 increased again be $5,22 \%$. The category of agriculture, forestry and fisheries experienced the highest growth amounting to $24,79 \%$ followed by category of industry processing of $18,08 \%$ and the category of trade and retail, repair of cars, and motorcycles by 17,97\% (BPS, 2020 : 898).

The economy of North Sumatra in the year 2017 decreased from 5,18\% to at $5.12 \%$. According to data from Bank Indonesia, the decline is mainly caused by household consumption, which tends to slow down, as economic conditions have 
not yet fully recovered household consumers tend to allocate the increase in income for the motif just in case. The source of the income is indicated as allocated in the form of savings and deposits, which is reflected in the amount of third party funds that is increasing, while it is sectoral, slowing Gross Domestic Product 2017 is also caused by the performance of the processing industry slowed down from 5.3\% in 2016 to $2.3 \%$ as commodity prices began to decline, especially in the second half of 2017 (the Bi.go.id).

The theory of economic growth of the neo-classical states economic growth depends on the development of the factors of production namely: capital, labor and technology. The larger the work force, which means the rate of population growth is high then the greater the income national and the higher economic growth (Lopez, 2014:2).

The total labor force in North Sumatra on the chart 1.2 look has fluctuated during the period 2015-2019. In the year In the year 2015 the total labor force of 6,391,098 soul, 2016 decreased compared to the year previous 6,362,909 soul, and increased again in 2017 menjadi6,743,277 soul, in 2018 the total labor force in North Sumatra back increased by $7,124,458$ soul but in the year 2019 experience lowering into 7,063,662 soul. Pakpak Bharat regency by the total labor force is the lowest and the city Medan is that the amount of labor high di North Sumatra since 2015 to 2019. Volatile total labor force this occurs because in the Province of North Sumatra is still dominated by educated people SMA.

The growth of an economy can not be separated from the role of education that will improve the quality of the workforce, thereby enabling the availability of the labor force that is skilled, reliable, and in accordance with national development. To improve the quality of the labor required education as one of the basic human to achieve sustainable economic development (Petianaet al, 2015: 53).
Since the year 2015-2019 labor force in North Sumatra, most of the educated high School/equivalent percentage of this group reached the highest level for 4 years. The second highest is the Junior high school and the highest order of the third is the SD while to the category of Diploma I/II/III/IV and the University are at the lowest level each year during 2015-2019.

Economic growth also can not be separated from the role of government consisting of a fiscal policy is a government action to regulate the course of the economy by determining the magnitude of the receipts and expenditures of the government each year which is reflected in the documents of the state Budget to the national and regional Budgets for the area or region. The magnitude of the contribution of local government expenditure on economic growth in the region is an opportunity that can be utilized optimally to drive the regional economy (BPS, 2018: 19).

Increased local government spending productive it also increased the economy of a region. One of the expenses of government productive expenditure sector of education (Sukirno in Lubis, 2014: 189).

The development of education achieved by improving equitable access, quality, relevance, and competitiveness. Budget allocation function of education reflects the government's efforts in providing services to the community in the field of education and as one of the efforts to meet the constitutional mandate that the allocation of the education budget at least $20 \%$ of expenditure (ministry of finance, 2019: 1).

In the year 2015 is the realization of the education expenditure is highest in North Sumatra sebesar12,739,268,776,946 and 2017 is the realization of educational spending low that $11,181,848,796,915$. Government spending sector basically, education is an investment to economic growth.

The policies outlined in the Budget it requires attention, especially in terms of the 
distribution of the budget, in order to create new sources of revenue for the region, so that government spending can effectively promote economic growth. This policy associated with the role of government as a provider of public goods (Sirojuzilam, 2015: 9).

In the research conducted by Sayed Suindyah D (2014: 147).The results of the research show that the number of workers who work have a significant influence on the increase of economic growth in East Java and the magnitude of the government spending will provide support to the implementation of the development, because with the increasing government spending will lead to increased economic growth.

This study strengthened by research conducted by Citra Ayu Basica Effendi Lubis (2014: 192). Show the results of that labor, the level of education and government spending to education significant positive effect on economic growth in Indonesia in the period of the years 2006-2012.

\section{LITERATURE REVIEW Economic Growth}

Economic growth is the increase in national income real gross domestic product in the long-term causes of goods and services produced in a society grow and the prosperity of society is increased (Parera, 2018:13).

\section{Labor}

Labor is the population in the working age aged 15-64 years or the number of the entire population in a country can produce goods and services if there is a demand for their labor, and if they want to participate in such activity (Mulyadi, 2017: 74). According to the Law Number 13 year 2003 , the labor is any person who is able to do work to produce goods and / or services to meet the needs of themselves and the community.

\section{Level Of Education}

Education is an important component and vital to the development, especially in increasing the economic growth which is both an input for the total production. Education also serves to improve productivity. In addition, the ability to absorb technology requires an increase in the quality of human resources. Someone who has the level of education the higher will get a job or income, the higher will be the future.

\section{Government Spending}

Government spending is a set of products that is produced, contains a choice or decision made by the government to provide public goods and services to the community. Government spending (Government Expenditure) is part of fiscal policy, namely an act of the government to regulate the course of the economy by determining the magnitude of the receipts and expenditures of the government each year which is reflected in the documents of the state Budget to the national and regional Budgets for the area or region. The purpose of fiscal policy is in order to stabilize prices, the level of output and employment and spur economic growth (Sukirno in Suindyah, 2011: 483).

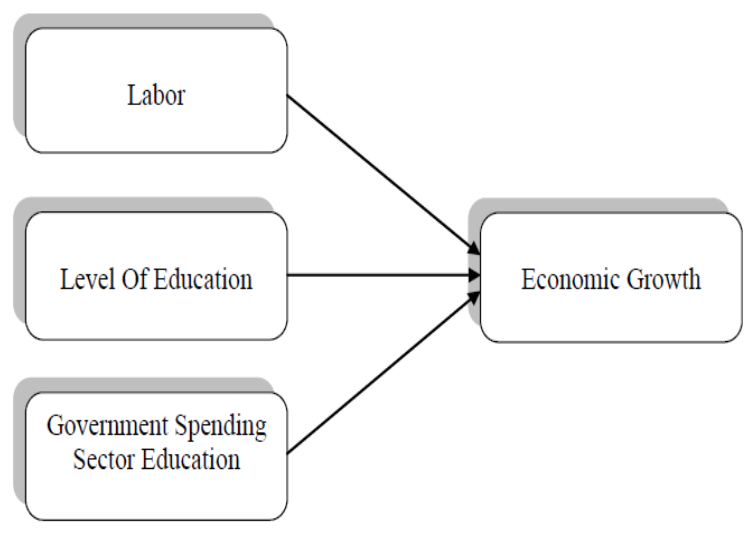

Figure 1. Conceptual Framework

\section{Hypothesis}

1. Labor significant positive effect on economic growth in North Sumatra 2015-2019 
2. The level of education significant positive effect on economic growth in North Sumatra 2015-2019

3. Government spending sector education significant positive effect on economic growth in North Sumatra 2015-2019

4. Labor, the level of education and government spending sector education simultaneously significant positive effect on economic growth in North Sumatra 2015-2019

\section{MATERIAL AND METHODS}

The research used is quantitative research, where the research quantitative is a study that uses the analysis of the data in the form of numerical or numbers, with the aim to develop and use mathematical models, theories, and hypotheses pertaining to phenomena investigated by researchers (Suryani, Hendrayadi, 2015: 109).

The type and source of data used in this research is secondary data, where secondary data is data that is not obtained directly from the object of research, the researchers get the data that had already been collected by another party. (Wordpress).

Source data obtained from the various parties, among others that is the Central Body of detailed statistics of the North Sumatra Province which is composed of 33 Districts/Cities in several publications, starting from year 2015 to 2019, the Agency of Finance and Asset Management North Sumatra and Literature as well as information written both derived from the relevant agencies, scientific journals and other related and the internet, which is associated with the research topic to obtain secondary data.

Data collection method used is documentation. Referring to some understanding of the proposed experts, the document is a collection or a significant amount of written material or film, in the form of data that will be written, viewed, stored, and rolled out in the research and easy access. The term document refers to materials such as photos, videos, movies, memos, letters, diaries, and records of clinical cases (Anggito, Setiawan, 2018: 146).

\section{RESULTS AND DISCUSSION \\ Analysis Testing The Fixed Effect Model}

Based on the test results obtained the results of the significance test. The results of the testing are as follows:

$\mathrm{Y}=4.686841-0.000655+0.011350+$ 0.000917

t-sig (0.0000) (0.3396) (0.0058) (0.0030)

1. Based on the results of the equation is known that the labor negative effect not significant to economic growth can be seen with a t-value sig is greater than $\alpha$ $=0.05$ so $(0.3396>0.05)$ this means that any increase in labor by 1 soul then the variable of economic growth will be decreased by $0.000655 \%$.

2. The level of education significant positive effect on economic growth can be seen with a t-value sig smaller $\alpha=$ 0.05 so (is $0.0058<0.05$ ) this means that any increase in the level of education $1 \%$ of the variable of economic growth will rise by $0.011350 \%$.

3. Government spending significant positive effect on economic growth can be seen with a t-value sig is smaller than $\mathrm{a}=0.05$ so $(0.0030<0.05)$ this means that any increase in the government spending sector education 1 billion dollars then the variable of economic growth will rise by $0.000917 \%$.

\section{The Analysis of The Influence of The Labour Towards Economic Growth}

Based on the estimation results, it can be seen that the variable labor negative effect not significant to economic growth in North Sumatra years 2015-2019 with a coefficient of -0.000655 and the probability of 0.3396 . The coefficient of -0.000655 that means that every increase of variable labor by 1 soul then proper growth of the economy will be decreased by $-0.000655 \%$, which means not in accordance with the initial hypothesis that the variable labor 
influential significant positive to economic growth in North Sumatra.

Not yet optimal power due to the level of education of most work North Sumatra still dominated by graduates of high School, the percentage of this group reached the highest level while the labor force graduate diploma I/II/II/IV and the university was at its lowest level during the period 2015-2019, causing low ability and the level of awareness of labor. In addition, the shift of the labor of man to the modern technology that caused the decline of labour of the province of North Sumatra.

This research is in line with research conducted by Farouq Syaifulla Haq (2017) entitled Analysis of the Influence of Investment, Employment and Level of Education On Economic Growth in Yogyakarta period 2009-2015, the results of this study indicate that labor has no effect on economic growth due to the modern technologies that replace human labor in the Special Region of Yogyakarta. This study is also in line with research that is conducted by Siti Hardiningsih Arifin (2017) titled the Influence of Investment, Labor and Rate of Consumption To Economic Growth in the City of Makassar from 2006 to 2015, with the results of the labor negatively affect economic growth this is because the workforce in the City of Makassar are not all derived from the Makassar City itself, but from outside the City of Makassar, in addition, most workers are placed not in accordance with the education and skills possessed.

\section{Analysis Of The Influence Of Level Of Education On Economic Growth}

Based on the results of the estimation can be seen that the variable level of education significant positive effect on economic growth in North Sumatra 2015-2019 with a coefficient of 0.011350 and the probability is 0.0058 . The coefficient of 0.011350 that means that any increase in the variable level of education by $1 \%$, the economic growth will increase by $0.011350 \%$.
This research is based on the theory of human capital which has the assumption that a can increase income through education. The function of education relating to human capital. Increasing educational opportunities will improve the quality of human resources so that productivity will also increase. Increased productivity will be able to increase the output of which then will have an impact on economic growth (Althofia, Agustina, 2015).

This means that in accordance with the initial hypothesis stated that the level of education significant positive effect on economic growth in North Sumatra years 2015 to 2019, and in line with the research done by H. Muh Rusdi and Haerati (2015) with the title Analysis of the Influence of Labor, Level of Education and Government Spending in the City of Makassar in 20042013, with the result that the level of education has a positive relationship significantly to economic growth in the City of Leeds during the period 2004-2013, and the variable level of education is a factor that is very dominant influence on economic growth in the City of Makassar compared to other variables. This research is also supported by research conducted by Dewi Kurniawati Sanusi et al(2014), entitled Analysis the Influence of the Amount of Labor, Education Level, Government Spending On Economic Growth and its Impact On Poverty in North Sulawesi years 2001-2010, in this study stated that the variable level of education affect positive significant impact on economic growth, which this means that the high level of education to graduated from high school and tamatanperguruan high, the higher the economic growth that occurred in the Province of North Sulawesi.

\section{Analysis Of The Influence Of Government Spending Sector Of Education To Economic Growth}

Based on the results of the estimation can be seen that the variable expenses of the government, the education 
sector is significant positive effect on economic growth in North Sumatra 20152019 with a coefficient of 0.000917 and the probability of 0.0030 . The coefficient of 0.000917 that means that any increase in variable expenses of the government, the education sector amounted to 1 billion dollars then economic growth will increase by $0.000917 \%$.

The greater government spending, the higher the economic growth. On the contrary the smaller the expenditure of the government, it is the lower the economic growth that will happen. In this study, based on the theory of Wagner, which suggests the development of government spending and the GDP. This means that in accordance with the initial hypothesis that states the government spending sector education effect positive significant to economic growth in North Sumatra can be accepted.

This research is in line with research conducted by Nurul Fitriani (2017) titled the Influence of Labor and Government Spending On Economic Growth in the Province of Yogyakarta years 2007-2015. Results showed that government spending together significant positive effect on economic growth in the Province of Yogyakarta. This research is also supported by Iis Surgawati (2020) with the title Government Spending and Economic Growth Hypothesis Keynes Versus the Theory of Wagner. Results showed that government spending on education and health is able to increase the economic growth of West Java.

\section{The analysis of Labor, Level of Education and the Influence of Government Spending Sector of Education To Economic Growth}

Based on estimation results that has been done then the test results show the value of $\mathrm{R}$-Squared is 0,892313 which means that the independent variables contained in the model, namely labor, level of education and government spending sector education simultaneously able to explain the dependent variable, namely the
Economic Growth of $89,23 \%$ while the rest $10.77 \%$ is explained by variables outside the model. Furthermore it is known that all the independent variables of labor, level of education and government expenditure of the education sector in North Sumatra simultaneously or together showed a significant influence on economic growth indicated by the value of Prob F-statistic is smaller than $0.05(\alpha=5 \%)$ that is equal to 0,000000 .

\section{CONCLUSIONS AND RECOMMENDATIONS CONCLUSIONS}

Based on the results of the analysis and discussion of the conclusions that can be drawn from the study is as follows:

1. Labor negative effect not significant to economic growth in North Sumatra years 2015-2019.

2. Level of education no significant positive effect on economic growth in North Sumatra years 2015-2019.

3. Government spending sector education significant positive effect on economic growth in North Sumatra 2015-2019.

4. Labor, the level of education and government spending sector education simultaneously significant positive effect on economic growth in North Sumatra 2015-2019, with R-squared $89 \%$.

\section{RECOMMENDATIONS}

Suggestions of researchers from the research that has been done is as follows:

1. The government of North Sumatra, it is suggested that the increase of expenditure on an ongoing basis and evaluate thoroughly to increase the economic growth of North Sumatra.

2. Sumatra Provincial Government North perlu intervene to improve the education of the people of North Sumatra with a way to give more scholarships to students achievement and also for students who are less able to continue their education to a higher level, so will 
be expected to improve the quality of human resources.

3. The need for awareness of each community to improve the quality and add insight to continue their education to level higher and participated in various seminars or workshops related to education and job specific.

4. For the private sector is expected to increase new business so it can absorb more labor and increase the productivity of labor in North Sumatra.

5. For further research it is recommended to add the variable and the years of research that is useful to see a larger influence between variables on economic growth in the long term.

\section{Acknowledgement: None}

\section{Conflict of Interest: None}

\section{Source of Funding: None}

\section{REFERENCES}

1. Anggito,Albi dan Setiawan,Johan. 2018. Metode Penelitian Kualititatif. CV Jejak. Jawa Barat.

2. Ajija,Shochrul R. Sari, Dyah W. Setianto Rahmat H. Primanti,Martha A. 2011.Cara Cerdas Menguasai Eviews Salemba Empat. Jakarta Selatan.

3. Ansofino. Jolianis. Yolamalinda. Arifindo, Hagi. 2016. Ekonometrika. Deepublish.Yogyakarta.

4. Azwar. 2016. Peran Alokatif Pemerintah melalui Pengadaan Barang/Jasa dan Pengaruhnya Terhadap Perekonomian Indonesia. Volume.20 No. 2 Agustus 2016.

5. Atahrim, Avanda Fahri. 2013. Analisis Pengaruh Tenaga Kerja dan Pengeluaran Pemerintah Terhadap Pertumbuhan Ekonomi Sektor Industri Kab/Kota di Provinsi Jawa Tengah.Skripsi, Fakultas Ekonomi dan Bisnis.Universitas Islam Negeri Syarif Hidayatullah. Jakarta.

6. Althofia, Nalyda Yola. Agustina, Neli. 2015. Pengaruh Pengeluaran Pemerintah untuk Pendidikan, Kesehatan dan Infrastruktur terhadap PDRB dan Penyerapan Tenaga Kerja di Provinsi Jawa
Barat tahun 2012. Volume 7, No 1, Juni 2015.

7. Barlas, Ahmad Walid. 2020. The Impact of Government Expenditure on Economic Growth in Afghanistan. ISSN 2615-3726. Volume 3 No 2. 2020.

8. Badan Pusat Statistik, 2015-2019. Provinsi Sumatera Utara Dalam Angka.

9. Badan Pusat Statistik. 2018. Financial Statistics of Province Government 20152018.

10. Effendie. 2017. Keuangan Negara Suatu Tinjauan Komperhensif dan Terpadu. Airlangga University Press. Surabaya.

11. Effendie. 2017. Keuangan Negara Suatu Tinjauan Komperhensif dan Terpadu. Airlangga University Press. Surabaya.

12. Farouq Haq Syaifulla. 2017. Analisis Pengaruh Investasi, Tenaga Kerja dan Tingkat Pendidikan Terhadap Pertumbuhan Ekonomi di daerah Istimewa Yogyakarta periode 2009-2015.

13. Fitriani, Nurul. 2017. Pengaruh Tenaga Kerja Dan Pengeluaran Pemerintah Terhadap Perumbuhan Ekonomi Di Provinsi Daerah Istimewa Yogyakarta tahun 20072015.

14. Gujarati, Damodar N. Dawn C. Porter. 2012. Dasar-dasar Ekonometrika. Salemba Empat. Jakarta Selatan.

15. Https://www.bi.go.id/id/publikasi/kajianekonomi-regional/sumut/Pages/KEKR-

Provinsi- Sumatera-Utara-Februari2018.aspx

16. Https://tepenr06.wordpress.com/2011/10/30 /teknik-pengumpulan-data

17. Https://dosen.perbanas.id/regresi-datapanel-2-tahap-analisis/

18. Http://www.dataapbn.kemenkeu.go.id/Dataset/Details/1007

19. Hasyim,AliIbrahim. 2016. Ekonomi Makro. Kencana. Jakarta

20. Http://balitbang.sumutprov.go.id/website/vi si_misi

21. Idris, Amiruddin. 2018. Ekonomi Publik. Deepublish.Yogyakarta.

22. Klasen, Stephan dan Francesca Lamanna. 2009. The Impact Of Gender Inequality In Education And Employment On Economic Growth New Evidence For A Panel Of Countries. ISSN 1466-4372. Volume 15 No 3. 2009.

23. Kahang, Merang. Saleh, Muhammad dan Suharto, Rachmad Budi. 2016. Pengaruh Pengeluaran Pemerintah Sektor Pendidikan 
dan Kesehatan Terhadap Indeks Pembangunan Manusia di Kabupaten Kutai Timur.ISSN 1411-1713. Volume 18 No 2. 2016.

24. Lubis, Citra Ayu Basica. 2014. Pengaruh Jumlah Tenaga Kerja Tingkat Pendidikan Pekerja dan Pengeluaran Pendidikan Terhadap Pertumbuhan Ekonomi.Volume 10 No 2. 2014.

25. Mankiw, N Gregory. 2011. Principles of E Economics Pengantar Ekonomi Makro. Salemba Empat.Jakarta.

26. Mulyadi, S. 2017. Ekonomi Sumber Daya Manusia. Rajagrafindo.Depok.

27. Petiana,Iga. Iranto, Dicky, dan Wibowo,Agus. 2015. Tingkat Pendidikan, Pengeluaran Pemerintah Sektor Pendidikan dan Pertumbuhan Ekonomi di Indonesia tahun 2008-2012. ISSN 2302-2663. Volume 3 No 1. 2015.

28. Parera, Jolyne Myrell. 2018. Aglomerasi Perekonomian Di Indonesia. CV IRDH. Purwokerto.

29. Rapanna, Patta dan Sukarno, Zulfikry. 2017. Ekonomi Pembangunan. CV Sah Media. Makasar.

30. Rusdi dan Haerati. 2015. Analisis Pengarauh Tenaga Kerja, Tingkat Pendidikan dan Pengeluaran Pemerintah Terhadap Pertumbhan Ekonomi di Kota Makasar tahun 2004-2013. Volume 11 No 1. 2015.

31. S Sitompul, RN Ichsan, L Nasution. 2021. The Influence of Exchange Rate, Inflation, For the Results of the Development Assets of Islamic Banks. Journal of Economics, Finance and Management Studies. Vol. 4, Issue 3 March 2021: 138-148.

32. Siti Arifin Hardiningsih. 2017. Pengaruh Investasi, Tenaga Kerja dan Tingkat Konsumsi Terhadap Pertumbuhan Ekonomi di Kota Makasar 2006-2015.

33. Sunusi, Dewi Kurniawati. Kumenaung, Anderson, Rotinsulu, Debby. 2014. Analisis Pengaruh Jumlah Tenaga Kerja, Tingkat Pendidikan, Pengeluaran Pemerintah pada
Pertumbuhan Ekonomi dan Dampaknya Terhadap Kemiskinan di Sulawesi Utara Tahun 2001-2010. Volume 14, No 2, Mei 2014.

34. Simeon, Ernest O. Odior. 2011. Government Spending on Education, Economic Growth and Long Waves in a CGE Micro-Simulation Analysis:The Case of Nigeria. ISSN 2048-125X. Volume 1 No 2. 2011.

35. Sun'an, Muammil. 2015. Ekonomi Pembangunan. Mitra Wacana Media. Jakarta.

36. Surgawati Iis. 2020. Pengaruh Pemerintah dan Pertumbuhan Ekonomi Hipotesis Keynes Versus Teori Wagner. Volume 1 No 1. Mei 2020.

37. Suryani dan Hendrayadi. 2015. Metode Riset Kuantitatif. Kencana. Jakarta.

38. Suindyah,Sayekti D. 2011. Pengaruh Investasi Tenaga Kerja dan Pengeluaran Pemerintah Terhadap Pertumbuhan Ekonomi di Provinsi Jawa Timur. ISSN 1411-0393.

39. Sirojuzilam. 2015. Pembangunan Ekonomi Regional. USUpress. Medan.

40. Tarmizi, Hasan Basri. 2013. Pertumbuhan Ekonomi dan Implikasinya.USUpress. Medan.

41. Widayati, Heni Wahyu. Laut Lorentino Togar dan Destiningsih Rian. 2019. Pengaruh Jumlah Tenaga Kerja, Tingkat Pendidikan dan Jumlah Pengangguran Terhadap Pertumbuhan Ekonomi Kabupaten Magelang. Dinamanic. Volume 1 No 2.

42. Zainal, Veithzal Rivai. Kamal, Haryadi, Muhammad, Natsir. 2014. The Economics Of Education. Gramedia. Jakarta.

How to cite this article: Sari J, Irsad, Rahmanta. Analysis of the influence of the amount of labor, level of education and government spending on economic growth in North Sumatera. International Journal of Research and Review. 2021; 8(4): 211-219. DOI: https://doi.org/ 10.52403/ijrr.20210428 